\title{
The Rohingya Refugee Crisis of Bangladesh: Gender Based Violence and the Humanitarian Response
}

\author{
Annekathryn Goodman ${ }^{1 *}$, Iftkher Mahmood ${ }^{2}$ \\ ${ }^{1}$ Department of Obstetrics and Gynecology, Massachusetts General Hospital, Boston, MA, USA \\ ${ }^{2}$ Hope Foundation for Women and Children of Bangladesh, Cox's Bazar, Bangladesh \\ Email:*agoodman@mgh.harvard.edu, iumahmood@gmail.com
}

How to cite this paper: Goodman, A., \& Mahmood, I. (2019). The Rohingya Refugee Crisis of Bangladesh: Gender Based Violence and the Humanitarian Response. Open Journal of Political Science, 9, 490-501. https://doi.org/10.4236/ojps.2019.93027

Received: May 13, 2019

Accepted: June 8, 2019

Published: June 11, 2019

Copyright (C) 2019 by author(s) and Scientific Research Publishing Inc. This work is licensed under the Creative Commons Attribution International License (CC BY 4.0).

http://creativecommons.org/licenses/by/4.0/

\section{(c) (i) Open Access}

\begin{abstract}
The current Rohingya refugee situation in Bangladesh has become one of the most protracted in the world. A significant number of Rohingya women fleeing Myanmar experienced sexual violence. Gender-Based Violence is a significant problem facing displaced vulnerable refugee populations especially women and children. Rohingya women continue to be vulnerable to GenderBased Violence within the Bangladesh refugee camps. There has been an enormous humanitarian response by the Bangladesh government, local Bangladeshi groups, and the international sector. This commentary summarizes what is known of the Rohingya experience and the humanitarian response.
\end{abstract}

\section{Keywords}

Gender-Based Violence, Sexual Violence, Rape, Rohingya Refugees, Bangladesh, Humanitarian Aid, Human Trafficking

\section{Background}

This commentary examines the history of Rohingya refugees to Bangladesh and focuses on the most recent refugee crisis that started in 2017 when over 730,000 Rohingyas fled Myanmar to the Cox's Bazar area of Bangladesh (Bhatia et al., 2018; UN, 2017a). The response of the humanitarian world and the people of and the government of Bangladesh to managing the consequences of systematic gender-based violence inflicted on the Rohingya women is reviewed.

Bangladesh is a South Asian country that is bordered by India on the West and North and Myanmar on the East. The Southern border faces the Bay of 
Bengal (Figure 1). Bangladesh, which won its independence as a separate sovereign nation from Pakistan in 1971, is the eighth most populated country in the world and is the most densely populated country in the world (UN, 2017c). Cox's Bazar, the district where Rohingyas has resettled, is one of the most impoverished regions of Bangladesh, already struggling to cope with extreme poverty, high population density, and the effects of regular natural disasters and climate change (Kiragu et al., 2011).

Bangladesh has intermittently received Rohingya refugees fleeing from Myanmar since World War two (Milton et al., 2017). There have been multiple Myanmar military actions against Rohingyas with more than twenty years of continuous Bangladesh camp settlements. Amnesty International summarized the timeline of Rohingya displacement to Bangladesh (Amnesty International, 2017). In 1977-1978, up to 200,000 Rohingya initially fled Myanmar to Bangladesh

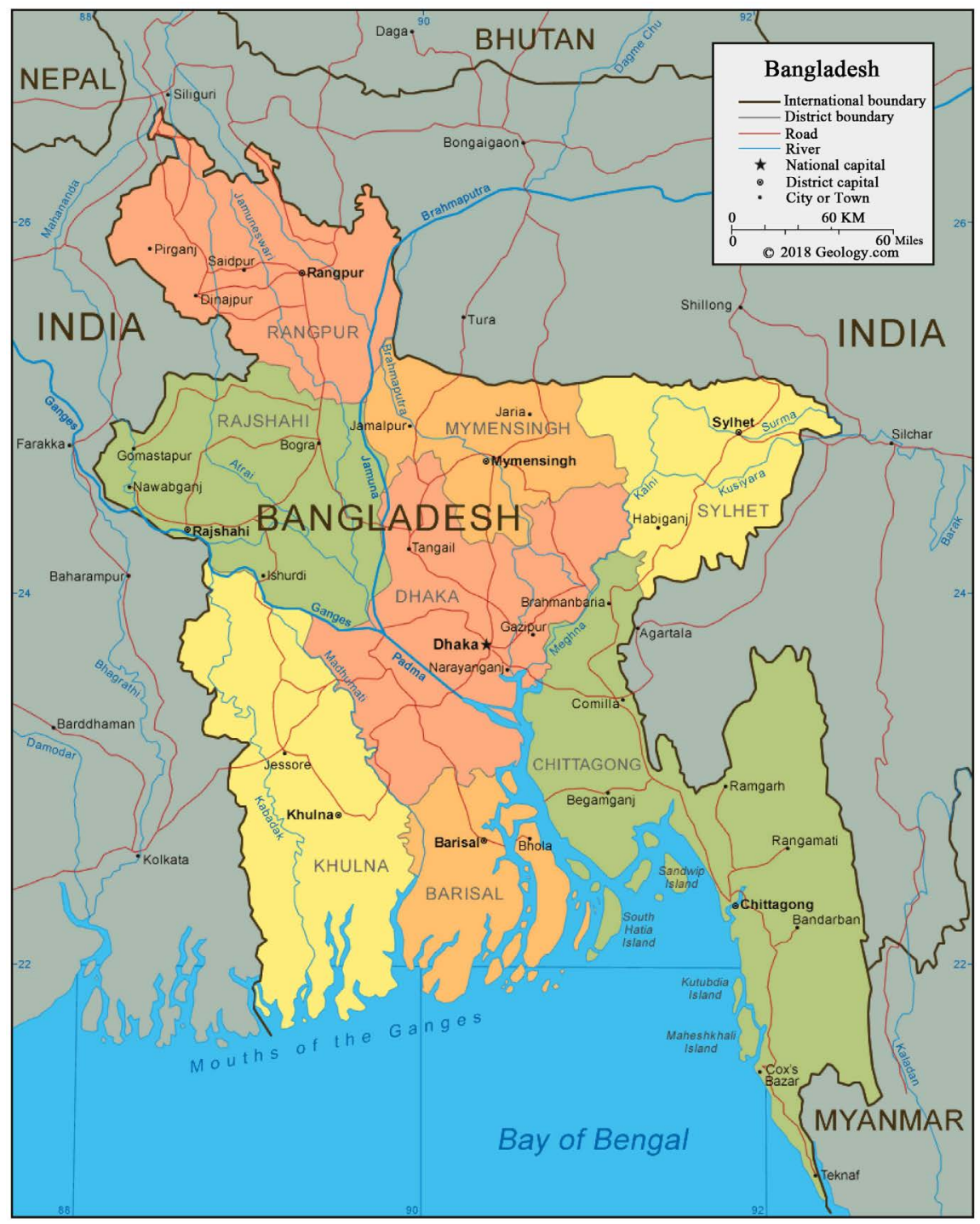

Figure 1. Map of Bangladesh. (From Geology.com,

https://geology.com/world/bangladesh-satellite-image.shtml). 
after a nationwide crackdown on "illegal immigration" and then returned to Myanmar in 1979. In 1982 Myanmar enacted the 1982 Citizenship Law depriving the Rohingya of citizenship. In 1991-1992 forced labor, torture including rape, arrests, and executions by Myanmar security forces led 250,000 Rohingya to flee from Myanmar to Bangladesh. In 2001 anti-Muslim riots across Myanmar displaced Rohingya. By 2012, state-supported violence between Muslims and Buddhists in Rakhine State led to deaths, destruction of property and mass displacement. Myanmar authorities separated the communities, and moved displaced Rohingya and other Muslim communities to camps where their movement was restricted. In October of 2016, a Rohingya armed group, the Arakan Rohingya Salvation Army (ARSA), attacked three police posts in Maungdaw and Rathedaung townships and killed nine police officers. The military responded with a major security operation marked by human rights violations. More than 87,000 Rohingya fled to Bangladesh over the following ten months.

On August 25, 2017, after ARSA attacks on Myanmar Border Guard Police Posts, the Myanmar military escalated its program of clearing out the Rohingya population of the Rakhine State in Myanmar, which created the most recent exodus of the Rohingya people (ReliefWeb, 2017). Since August 2017, more than 730,000 Rohingya, including 400,000 children, have fled violence in Myanmar and settled in Cox's Bazar District, Bangladesh (ReliefWeb, 2019). Currently as of April 2019, an estimated 911,359 Rohingya refugees are sheltered in Cox's Bazar, including 34,172 refugees from Myanmar who registered before 31st August 2017 (WHO, 2019). Figure 2 shows the locations of the Rohingya refugee camps. Constant updates to the camps sites, locations, and population numbers

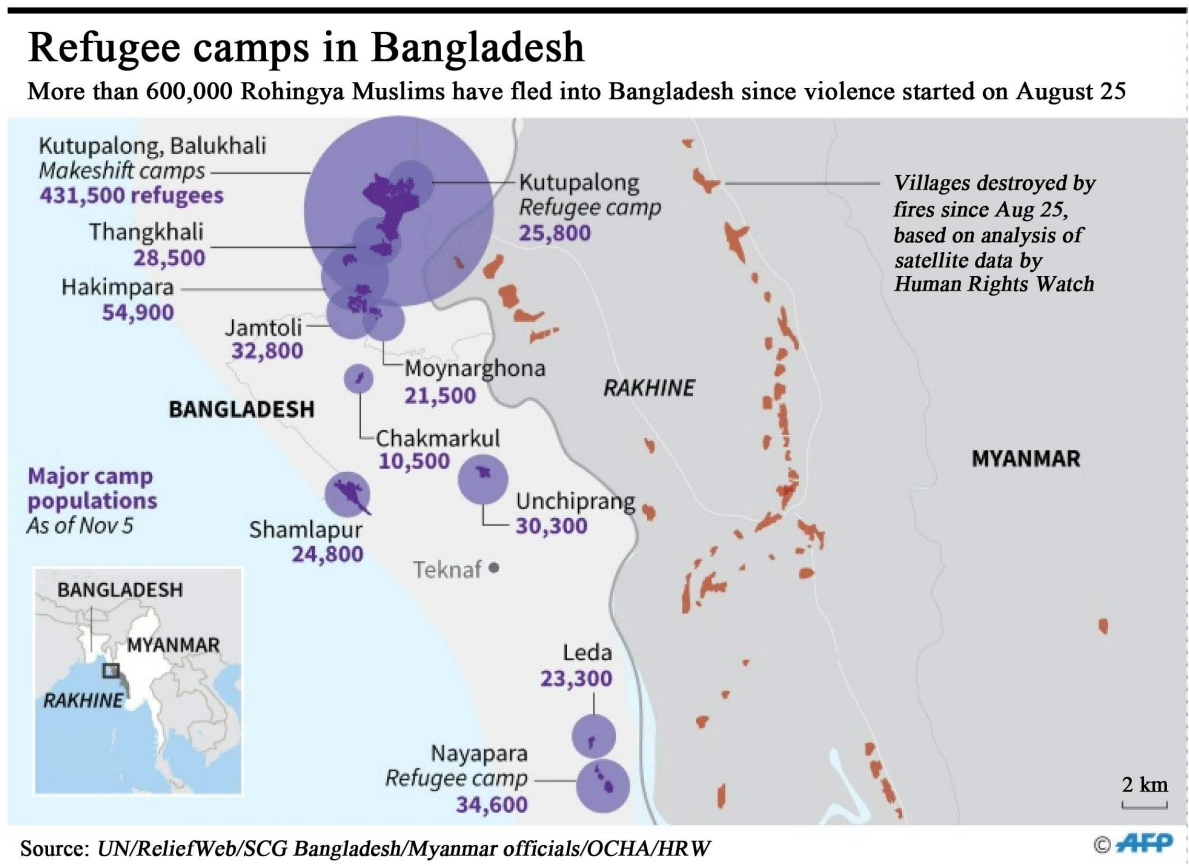

Figure 2. Rohigya Refugee Camps in Bangladesh (Source: UN /Relief Web https://reliefweb.int/country/bgd). 
can be obtained from OCHA (2019) Services Humanitarian response, Maps/Infographics

(https://www.humanitarianresponse.info/en/operations/bangladesh/camp-coord ination-and-camp-management/infographics/table).

The Rohingya population of Myanmar has been exposed to chronic and prolonged persecution and conflict. The refugees who have fled Myanmar are vulnerable to significant mental health concerns such as post-traumatic stress disorder, anxiety, depression, and risk of suicide (Tay et al., 2019). The current Rohingya refugee situation in Bangladesh has become one of the most protracted in the world. Figure 3 shows a typical area of the Rohingya refugee camp in Cox's Bazar region.

\section{Gender-Based Violence}

One aspect of Rohingya persecution has been targeted sexual and gender-based violence (Human Rights Watch, 2018). Gender-Based Violence (GBV) is defined as a violation of universal human rights protected by international human rights conventions, including the right to security of person, the right to the highest attainable standard of physical and mental health, the right to freedom from torture or cruel, inhuman, or degrading treatment, and the right to life (IASC, 2015).

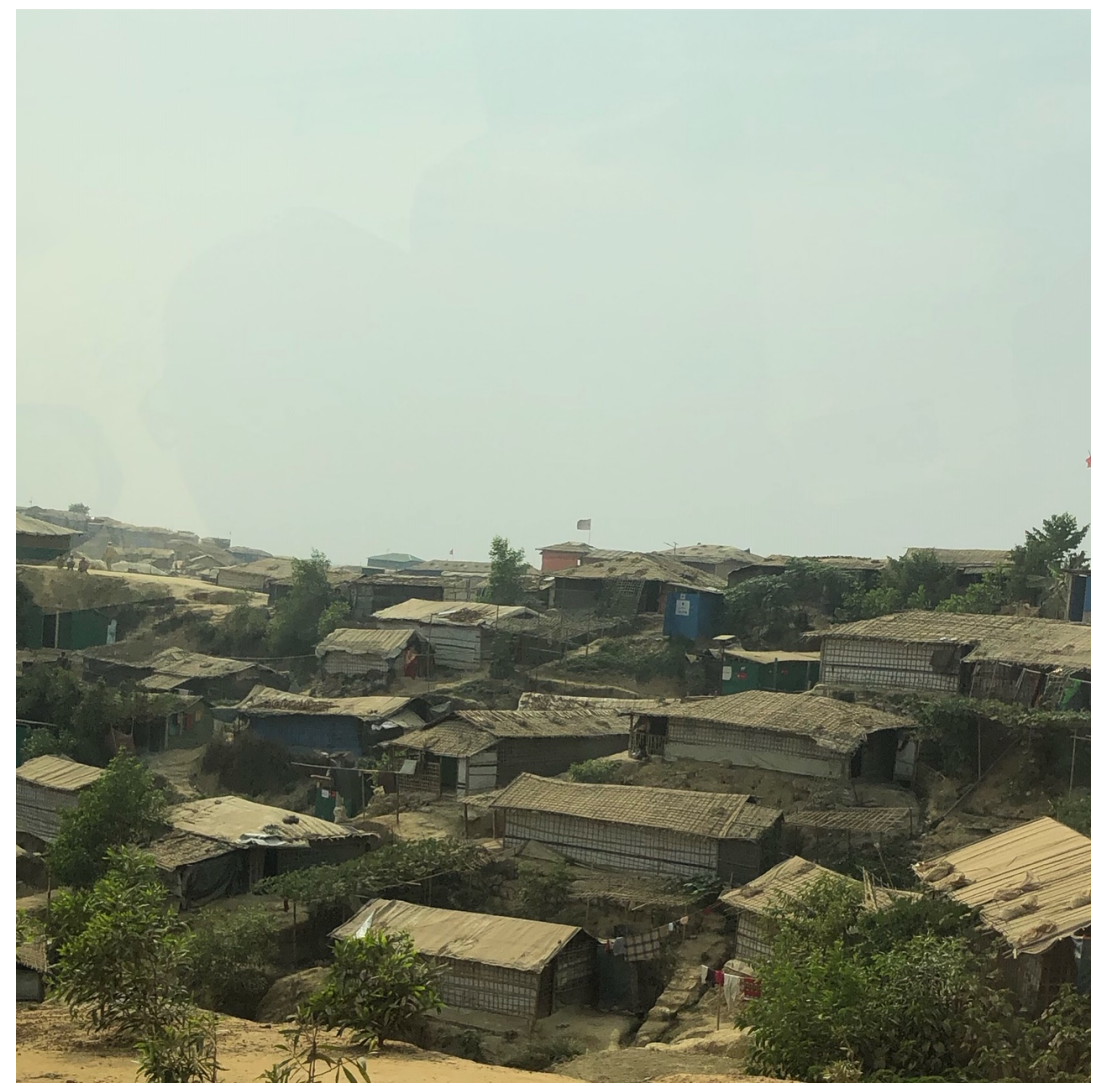

Figure 3. Camp \#4 Rohingya Refugee camp, Cox’s Bazar (Source: A goodman, February 2019). 
The Committee on the Elimination of all Forms of Discrimination Against Women regard the prohibition of GBV as a principle of customary international law (CEDAW/C/GC/35). In that vein, sexual violence, when linked to an armed conflict constitutes a war crime, and in certain cases a crime against humanity, torture, or genocide (Bernard \& Durham, 2014). It remains a significant and prevalent factor in humanitarian crises and in refugee camps (Ferris, 2007; Agier et al., 2002; O'Brien, 2017). For decades, the Myanmar army targeted ethnic minorities with the systematic use of rape (Flint 2017). In interviews with Rohingya women, they described rape as a form of torture and psychological and social intimidation (Farzana, 2017; Human Rights Watch, 2017).

An analysis of qualitative data from international agencies and refugee testimony confirms the reliability of stories of conflict-related sexual violence and ethnic cleansing in Rakhine State (Hutchinson, 2018). A high proportion of Rohingya women and girls arriving in Bangladesh were pregnant, which may be seen as an indicator of increased conflict related sexual violence and abuse (Hutchinson, 2018; UN, 2018). Since late August 2017 the United Nations Population Fund (UNFPA) has assisted 3500 Rohingya women who have been sexually assaulted. Figures from other conflicts show that only about $6 \%$ to $7 \%$ of the women seek medical care after sexual violence (UNFPA, 2018a). Estimates are that 58,700 Rohingya women and girls have experienced sexual violence (Hutchinson, 2018). Twelve percent of families in the refugee camps were exposed to sexual abuse, humiliation, or exploitation, $8.1 \%$ said they had been exposed to rape (forced, unwanted sex with a stranger, acquaintance, or family member) while $6.1 \%$ had witnessed physical or sexual violence and abuse (Riley et al., 2017). In a statement to the Security Council, Special Representative on Sexual Violence in Conflict, Pramila Patten, notes, "The acts described were by no means isolated incidents: Every woman or girl I spoke with reported having either endured or witnessed sexual violence" (UN, 2017b).

The actual number of girls and women who have died secondary to sexual violence is unknown but MSF estimates at least $2.6 \%$ of those assaulted have died (MSF, 2018). Most of the victims did not receive post-assault medical care such as emergency contraception and prophylaxis against HIV infection (Human Rights Watch, 2017). Additionally, they are vulnerable to increased rates of sexually transmitted diseases (Hossain et al., 2018).

Despite refuge across the border in Bangladesh, GBV continues to be widespread in refugee camps (Nordby, 2018). Rohingya women and girls are vulnerable because of their gender, refugee status and ethnic affiliation from a number of different perpetrators; both displaced Rohingya men and men from the host community. One risk factor for continued assaults that occur in the refugee camps is the vulnerability created by the breakdown of family and community structures. ReliefWeb identified that children, adolescents and women in both the Rohingya and host communities are exposed to high levels of violence, abuse and exploitation including sexual harassment, child labor and child marriage and are at high risk of being trafficked (ReliefWeb, 2017). The stressful circums- 
tances of refugee life put women at risk for GBV both within the household and when they seek work in the community (Akhter \& Kusalabe, 2014). BBC (2018) reported how Rohingya children have been trafficked for sexual purposes into Bangladesh and Cox Bazar area from the refugee camps. Several reports of Rohingya women and girls being trafficked into, and out of Bangladesh, documents the exploitation of severe vulnerability (Milton et al., 2017). In 2019, Al Jazeera reported that dozens of women are now regularly arriving in Malaysia to marry Rohingya men, reviving a form of transnational human trafficking that once moved thousands of Rohingya a year across borders (Al Jazeera, 2019a). An additional, 6,000 Rohingya children are identified as unaccompanied opening up vulnerability to trafficking, early marriage and additional forms of sexual exploitation (ReliefWeb, 2019). A recent investigation documented the rescue of 23 Rohingya girls who were being trafficked to Malaysia from Bangladesh; aid workers who specialize in identifying human trafficking report that they are only identifying a small percentage of the victims (Al Jazeera, 2019b).

\section{Cox's Bazar-The Humanitarian Response}

The United Nations High Commissioner for Refugees (UNHCR), along with other national and international agencies, has been providing the Government of Bangladesh with coordinated assistance for the refugees. There are now over 150 Non government organizations (NGOs) working in the Cox's Bazar area (ISCG, 2019; Wake \& Bryant, 2018). There has been a call to establish safe spaces and a multipronged action against Gender-Based Violence by the various NGOs that are working in the Rohingya refugee camps of Bangladesh (Hossain, Sultana, \& Das, 2018; IAWG, 2018).

The Gender-Based Violence (GBV) Sub Sector coordination structure in Cox's Bazaar was established in May 2017 and reinforced and expanded to respond to the needs of the massive influx of the Rohingya refugees in Bangladesh in August of 2017 (OCHA, 2019). In addition, the inter-agency working group (IAWG) on reproductive health in crises has published a minimum initial service package (MISP), which includes the following recommendations:

1) ENSURE the health sector/cluster identifies an organization and a Reproductive health officer to lead implementation of the MISP.

2) PREVENT AND MANAGE the consequences of sexual violence (e.g. improve security related to WASH, treat victims)

3) REDUCE HIV transmission Ensure safe blood transfusion practice; facilitate and enforce respect for standard (universal) precautions; make free condoms available.

4) PREVENT excess maternal and newborn morbidity and mortality, ensure availability of basic and comprehensive emergency obstetric care, including newborn care services. Establish a referral system to higher-level care where needed Provide clean delivery kits to visibly pregnant women when access to a health facility is not possible.

5) PLAN for comprehensive reproductive health services, integrated into pri- 
mary health care as the situation permits.

The Gender-Based Violence Sub-Sector in Cox's Bazar is led by the United Nations Population Fund (UNFPA, 2018b). It is made up of more than twenty-eight standing member organizations; including the United Nations, International Non-governmental organizations, Non-government organizations and government agencies that work within the Rohingya refugee camps and the surrounding affected host community locations. One Bangladeshi NGO, Hope Foundation, works on this issue by strengthening outreach and care to pregnant women (Severi, 2019). Hope Foundation is an active member is the sub-sector. In 2018, Hope Foundation, in partnership with UNFPA, trained 102 health professionals to respond to instances of GBV (Hope Foundation). The trainings are an attempt to strengthen local capacity efforts in combating and responding to the ongoing sexual and gender-based violence suffered within the camps and host community.

As mentioned previously, women and girls face social and safety barriers to accessing health clinics. Indeed, twenty-three per cent of girls and 57 per cent of women reported feeling unsafe when simply using latrines (ReliefWeb, 2019). While, approximately 55,000 women require basic or comprehensive emergency obstetric care, UNFPA reports that a mere $22 \%$ of this total are utilizing health facilities to give birth (ReliefWeb, 2018). In a survey of Rohingya households the majority of pregnant women (56.6\%) received no antenatal care. Seventy-three percent of Rohingya women delivered at home without a certified birth attendant (Bhatia et al., 2018). Recognizing that safety and transportation had become a barrier to receiving adequate SRH care, Hope Foundation expanded emergency transportation networks in 2018. The efforts are an illustration of an attempt to strengthen the local response to the issue suffered within both the host community and inside of the camps. As thousands, then tens of thousands of refugees surged into Bangladesh, it was local responders-volunteers from nearby communities, local NGOs and civil society groups, and Bangladeshi authorities-who first rushed to help in large numbers (Ahmed, 2018). Today, those same entities, like the Hope Foundation, are demanding a presence in conversations such as those in responding and combating to issues of GBV within their communities.

The goal of the sub sector is to prevent and respond to Gender-Based Violence through strengthening community-based GBV programming. The key strategic objectives of the Sub-Sector include 1) to ensure access to quality multi-sector GBV response services for survivors; 2) to build capacity of GBV service providers and other stakeholders to deliver quality care in line with best practices and minimum standards for humanitarian settings; 3 ) to enable active participation of affected communities in GBV awareness raising, response, prevention and risk mitigation; 4) to enhance GBV risk mitigation across humanitarian sectors and with the government; 5) to strengthen co-ordination and planning for sustainability of the GBV response. 


\section{Conclusion}

This commentary reviews the plight of the Rohingya women, focuses on their experience of sexual violence, and summarizes the national and international response to this crisis. The significance of this study is the importance of documenting the role of gender based violence as both part of a strategy of persecution of a people and also a pervasive threat to women in an insecure landscape. The limitation of this review is the inability to fully capture and to document the impact of rape and sexual violence on the physical and mental health outcomes for these women.

Bangladesh is one of the most densely populated countries in the world. In October 2017, there was a sudden influx of over 730,000 Rohingya refugees into Bangladesh after an extraordinary upsurge of violence against this people by the Myanmar government. Bangladesh was suddenly confronted with managing an enormous addition to their population (population 170 million). The Rohingya came across with no sustainable means of survival-just the clothes on their backs. They were unvaccinated, traumatized, in grief over multiple family losses, and finally, traumatized by the systematic rape of the women. The events of August 2017 was a sudden onset disaster for Bangladesh vis-a-vis the threat and impact of a huge unvaccinated population on the host population, the environmental and economic consequences, the political challenges of managing a politically complex international crisis, the negotiations with Myanmar, and the risk of increased activity of local and imported radical Islamic terror groups which Bangladesh has been actively fighting for years (Milton et al., 2017).

There has been an enormous humanitarian response by the Bangladesh government, local Bangladeshi groups, and the international sector. The response has evolved to include a subgroup of twenty-eight NGOs focused on Gender-Based Violence. However, different programs are not ideally coordinated due to power politics (Wake \& Bryant, 2018). In addition, without addressing the underlying human right issues and statelessness of the Rohingya refugees, it may be impossible to fully manage the health needs of this traumatized group and integrate them into the larger society of Bangladesh (Wali et al., 2018). In the setting of political uncertainty and lack of protection, violence and abuse of the most vulnerable groups, women and children, will continue.

The challenges for outreach for sexually traumatized women are great. In this deeply traditional Muslim society, Rohingya women stay mostly indoors. In addition, there has been potential and actualization of continuing sexual abuse of both women and children within the refugee camps. Additionally, there continues to be limited reproductive health care in the camps (Singh et al., 2018).

Looking forward, capacity of response, complementarity among different groups of humanitarian actors and localization of services by supporting Bangladeshi efforts are needed. Ultimately these responses and especially the response to and mitigation of GBV must be grounded in meeting humanitarian needs and serving the needs of the affected Rohingya population and the local 
host community.

\section{Conflicts of Interest}

The authors declare no conflicts of interest regarding the publication of this paper.

\section{References}

Agier, M., Nice, R., \& Wacquant, L. (2002). Between War and City: Towards an Urban Anthropology of Refugee Camps. Ethnography, 3, 317-341. https://doi.org/10.1177/146613802401092779

Ahmed, K. (2018). The New Humanitarian: Local Aid Groups Want More of a Say in the Rohingya Refugee Response. 18 September 2018.

https://www.thenewhumanitarian.org/news-feature/2018/09/18/local-aid-groups-wantmore-say-rohingya-refugee-response

Akhter, S., \& Kusakabe, K. (2014). Gender-Based Violence among Documented Rohingya Refugees in Bangladesh. Indian Journal of Gender Studies, 21, 225-246. https://doi.org/10.1177/0971521514525088

Al Jazeera (2019a). Rohingya Women, Girls Being Trafficked to Malaysia for Marriage. 8 May 2019.

https://www.aljazeera.com/indepth/features/rohingya-women-girls-trafficked-malaysia -marriage-190507212543893.html

Al Jazeera (2019b). Rohingya Girls Rescued from Traffickers in Bangladesh. 12 May 2019. https://www.aljazeera.com/news/2019/05/rohingya-girls-rescued-traffickers-banglades h-190512101949513.html

Amnesty International (2017). Timeframe of Rohingya Displacement. Amnesty International. Caged without a Roof: Apartheid in Myanmar's Rakhine State. https://www.amnesty.org/en/documents/asa16/7484/2017/en/

BBC (2018). The Rohingya Children Trafficked for Sex. https://www.bbc.com/news/world-asia-43469043

Bernard, V., \& Durham, H. (2014). Sexual Violence in Armed Conflict: From Breaking the Silence to Breaking the Cycle. International Review of the Red Cross, 96, 427-434. https://doi.org/10.1017/S1816383115000442

Bhatia, A., Mahmud, A., Fuller, A., Shin, R., Rahman, A., Shatil, T. et al. (2018). The Rohingya in Cox's Bazar: When the Stateless Seek Refuge. Health and Human Rights, 20, $105-122$.

Farzana, K. F. (2017). Memories of Burmese Rohingya Refugees: Contested Identity and Belonging (pp. 103-106). New York, NY: Palgrave Macmillan. https://doi.org/10.1057/978-1-137-58360-4

Ferris, E. (2007). Abuse of Power: Sexual Exploitation of Refugee Women and Girls. Signs, 32, 584-591. https://doi.org/10.1086/510338

Hossain, M. M., Sultana, A., \& Das, A. (2018). Gender-Based Violence among Rohingya Refugees in Bangladesh: A Public Health Challenge. Indian Journal of Medical Ethics, 3, 260. https://doi.org/10.20529/IJME.2018.045

Hossain, M. M., Sultana, A., Mazumder, H., \& Munzur-E-Murshid, M. (2018). Sexually Transmitted Infections among Rohingya Refugees in Bangladesh. The Lancet HIV, 5, e342. https://doi.org/10.1016/S2352-3018(18)30140-1

Human Rights Watch (2017). All My Body Was Pain. Sexual Violence against Rohingya 
Women and Girls in Burma.

https://www.hrw.org/report/2017/11/16/all-my-body-was-pain/sexual-violence-against -rohingya-women-and-girls-burma

Human Rights Watch (2018). Sexual Violence by the Burmese Military against Ethnic Minorities: Testimony of Skye Wheeler at the Tom Lantos Human Rights Commission. https://www.hrw.org/news/2018/07/25/sexual-violence-burmese-military-against-ethni c-minorities

Hutchinson, S. (2018). Gendered Insecurity in the Rohingya Crisis. Australia Journal of International Affairs, 72, 1-9. https://doi.org/10.1080/10357718.2017.1402291

IASC Inter-Agency Standing Committee (2015). IASC Guidelines for Integrating Gender-Based Violence Interventions in Humanitarian Action, 2015.

https://interagencystandingcommittee.org/working-group/documents-public/iasc-guid elines-integrating-gender-based-violence-interventions

Inter-Agency Working Group (IAWG) (2018). Interagency Field Manual on Reproductive Health in Humanitarian Settings. http://iawg.net/

Inter-sector Coordination Group (ISCG) (2019). Humanitarian Response Bangladesh: NGO Support.

https://www.humanitarianresponse.info/en/operations/bangladesh/ngo-support

Kiragu, E., Li Rosi, A., \& Morris, T. (2011). States of Denial-A Review of UNHCR's Response to the Protracted Situation of Stateless Rohingya Refugees in Bangladesh. Policy Development and Evaluation Service, UNCHR. https://www.unhcr.org/4ee754c19.pdf

Medecins Sans Frontieres (MSF) (2018). "No One Was Left": Death and Violence against the Rohingya in Rakhine State, Myanmar.

https://www.doctorswithoutborders.ca/sites/default/files/2018_-_03_-_no_one_was_lef t_-_advocacy_briefing_on_mortality_surveys.pdf

Milton, A. H., Rahman, M., Hussain, S., Jindal, C., Choudhury, S., Akter, S. et al. (2017). Trapped in Statelessness: Rohingya Refugees in Bangladesh. International Journal of Environmental Research and Public Health, 14, 942.

https://doi.org/10.3390/ijerph14080942

Nordby, L. (2018). Gender-Based Violence in the Refugee Camps in Cox Bazar-A Case Study of Rohingya Women's and Girls' Exposure to Gender-Based Violence. Thesis, Uppsala: Uppsala Universitet.

http://www.diva-portal.org/smash/get/diva2:1219686/FULLTEXT01.pdf

O’Brien, M. (2017). Criminalising Peacekeepers Modernising National Approaches to Sexual Exploitation and Abuse. New York: Palgrave Macmillan, Secaucus.

OCHA (2019). Humanitarian Response: Gender Based Violence. https://www.humanitarianresponse.info/en/operations/bangladesh/gender-based-viole $\underline{\text { nce-gbv }}$

OCHA Services Humanitarian Response (2019). Maps/Infographics. https://www.humanitarianresponse.info/en/operations/bangladesh/camp-coordination -and-camp-management/infographics/table

ReliefWeb (2017). Bangladesh: Humanitarian Situation Report No. 16 (Rohingya Influx), 24 December 2017.

https://reliefweb.int/report/bangladesh/bangladesh-humanitarian-situation-report-no16-rohingya-influx-24-december-2017

ReliefWeb (2018). Women and Girls Critically Underserved in the Rohingya Humanitarian Response. 22 February 2018.

https://reliefweb.int/report/bangladesh/women-and-girls-critically-underserved-rohing ya-humanitarian-response 
ReliefWeb (2019). Humanitarian Action for Children 2019-Bangladesh. Report from UN Children's Fund, 30 January 2019.

https://reliefweb.int/report/bangladesh/humanitarian-action-children-2019-bangladesh

Riley, A., Varner, A., Ventevogel, P., \& Hasan, T. (2017). Daily Stressors, Trauma Exposure, and Mental Health among Stateless Rohingya Refugees in Bangladesh. Transcultural Psychiatry, 54, 304-331. https://doi.org/10.1177/1363461517705571

Severi, L. (2019). In Conversation with: HOPE Foundation for Women and Children of Bangladesh. United Nations Foundation.

http://poweringhc.org/in-conversation-with-hope-foundation-for-women-and-childre n-of-bangladesh/

Singh, N. S., Aryasinghe, S., \& Smith, J. (2018). A Long Way to Go: A Systematic Review to Assess the Utilisation of Sexual and Reproductive Health Services during Humanitarian Crises. BMJ Global Health, 3, e000682.

https://doi.org/10.1136/bmjgh-2017-000682

Tay, A. K., Riley, A., Islam, R., Welton-Mitchell, C., Duchesne, B., Waters, V., Varner, A., Moussa, B., Mahmudul Alam, A. N. M, Elshazly, M. A., Silove, D., \& Ventevogel, P. (2019). The Culture, Mental Health and Psychosocial Wellbeing of Rohingya Refugees: A Systematic Review. Epidemiology and Psychiatry Sciences, 22, 1-6. https://doi.org/10.1017/S2045796019000192

United Nations (UN) (2017a). Committee on the Elimination of Discrimination against Women (CEDAW). CEDAW General Recommendation No. 35 on Gender-Based Violence against Women, Updating General Comment No. 19. https://tbinternet.ohchr.org/Treaties/CEDAW/Shared\%20Documents/1_Global/CEDA W_C_GC_35_8267_E.pdf

United Nations (UN) (2017b). Statement by the Special Representative of the Secretary-General on Sexual Violence in Conflict, Ms. Pramila Patten-Security Council Briefing on Myanmar. 12 December 2017.

https://www.un.org/sexualviolenceinconflict/statement/statement-by-the-special-representa tive-of-the-secretary-general-on-sexual-violence-in-conflict-ms-pramila-patten-security-co uncil-briefing-on-myanmar-12-december-2017/

United Nations (UN) (2017c). World Population Prospects 2017. https://population.un.org/wpp/DataQuery/

United Nations (UN) (2018). For Rohingya Refugees, Imminent Surge in Births Is Traumatic Legacy of Sexual Violence-Special Report.

https://reliefweb.int/report/bangladesh/rohingya-refugees-imminent-surge-birthstrau matic-legacy-sexual-violence-special

United Nations Population Fund (UNFPA) (2018a). One Year on, Rohingya Women and Girls Seek Safety-And a Chance to Heal. 24 August 2018.

https://www.unfpa.org/news/one-year-rohingya-women-and-girls-seek-safety- $\% \mathrm{E} 2 \% 8$ 0\%93-and-chance-heal

United Nations Population Fund (UNFPA) (2018b). Sexual and Reproductive HEALTH Needs Immense among Rohingya Refugees. 29 June 2018.

https://www.unfpa.org/news/sexual-and-reproductive-health-needs-immense-among-r ohingya-refugees

Wake, C., \& Bryant, J., HPG Working Paper (2018). Capacity and Complementarity in the Rohingya Response in Bangladesh. https://www.odi.org/sites/odi.org.uk/files/resource-documents/12554.pdf

Wali, N., Chen, W., Rawal, L. B., Amanullah, A., \& Renzaho, A. (2018). Integrating Human Rights Approaches into Public Health Practices and Policies to Address Health 
Needs amongst Rohingya Refugees in Bangladesh: A Systematic Review and Meta-Ethnographic Analysis. Archives of Public Health, 76, 59.

https://doi.org/10.1186/s13690-018-0305-1

WHO (World Health Organization) (2019). Bangladesh Emergency Rohingya Crisis. Biweekly Situation Report \#09, 24-30 April 2019.

http://www.searo.who.int/bangladesh/biweeklysitrep09cxbban2019.pdf 